\title{
Jezuicki ośrodek badań historycznych w Krakowie
}

\author{
The Jesuit Historical \\ Research Centre in Krakow
}

Kiedy w latach 1900-1906 ukazało się monumentalne, pięciotomowe (11 woluminów) dzieło Jezuici w Polsce Stanisława Załęskiego (1843-1908)1, uznano, że wyjaśni ono wszechstronnie wszystkie aspekty działalności Towarzystwa Jezusowego w Polsce. Dzieło Załęskiego zachowało do dzisiaj swoją wartość i bywa uznawane za bardzo bogate źródło do dziejów zakonu, traktujące o jego różnorodnej działalności, z którego należy nadal korzystać, nawet choćby nie podzielało się wszystkich jego wniosków i ocen. Zresztą Załęski przystępując do opracowania swego dzieła nie miał ani wzorów, ani poprzedników wśród innych narodowości, nie dysponował też żadnymi opracowaniami monograficznymi ułatwiającymi tworzenie syntezy².

S. Rzepiński, Ks. Stanistaw Zatęski T.J., Kraków 1908, s. 8.

2 S. Załęski, Jezuici w Polsce, t. 1-5. t. 1: Walka z różnowierstwem, 15551608, Lwów 1900, ss. XVI + 820; t. 2: Praca nad spotegowaniem ducha wiary i pobożności, 1608-1648, Lwów 1901, ss. XVI + 764; t. 3: Prace misyjne nad ludem, 1648-1773, Lwów 1902, ss. XX + 1244; t. 4: Dzieje 153 kolegiów i domów jezuitów w Polsce, Kraków 1905, ss. XXXVIII + 1882; t. 5: Jezuici w Polsce porozbiorowej, 1773-1905, Kraków 1906, ss. XX + 1300.

SLOWA KLUCZOWE

historia jezuitów, źródła historyczne, Stanisław Załęski, Stanisław Bednarski, Ludwik Grzebień, jezuicki ośrodek badań historycznych

KEYWORDS

the history of Jesuits, historical sources, Stanisław Załęski, Stanisław Bednarski, Ludwik Grzebień, the Jesuit historical research centre 
Z czasem pojawiało się wiele krytyk dzieła Załęskiego. Okazało się, że podstawowym niedostatkiem jego opracowania był brak wszechstronności, zarówno w przedstawieniu wszystkich problemów związanych $\mathrm{z}$ działalnością zakonu, jak i w wykorzystaniu źródeł. Nie mogło być inaczej, bo zadanie którego podjął się autor przerastało siły jednego człowieka i długość jednego życia. Załęski opracował obszernie i sumiennie chronologię i historię polityczną zakonu, jego kolegiów, zaś jego dzieje wewnętrzne i kulturalne potraktował drugorzędnie. Nic więc dziwnego, że w 30 lat później Stanisław Bednarski (1896-1942), uczeń prof. Stanisława Kota, znawca ducha zakonu poświadczonego w źródłach, zmarły w sile wieku w obozie koncentracyjnym w Dachau, mógł wyliczyć główne braki dzieła Załęskiego:

Tak ważne zagadnienia, jak walka $\mathrm{z}$ protestantyzmem, teologia polemiczna, ascetyka, urabianie duszy i obyczaje szlachty, wymowa kościelna, praca duszpasterska, jej metody, zasięg, skutki, szkolnictwo, działalność na polu sztuki kościelnej, wreszcie działalność gospodarcza (gospodarka rolniczo-przemysłowa na folwarkach, handel, stosunki społeczne), te wszystkie zagadnienia zostały przedstawione albo tylko bardzo fragmentarycznie, albo nawet zupełnie nietknięte ${ }^{3}$.

Dalej Bednarski omówił szczegółowo metodę historyczną swego poprzednika w doborze źródeł, pisząc:

Ograniczywszy sobie siłą faktu zakres zagadnień, Załęski wyeliminował tym samym całe grupy źródeł. I tak pominął zupełnie ogromną spuściznę rękopiśmienną polskich jezuitów z zakresu teologii, filozofii, ascetyki i przedmiotów nauczania szkół średnich. O gospodarce w majątkach i działalności na polu sztuki podaje wiadomości pozbierane raczej przypadkowo i ubocznie. W wyborze i opracowaniu źródeł do reszty zagadnień, a zwłaszcza historii politycznej jezuitów, historii kolegiów i walki $\mathrm{z}$ reformacją, zastosował, jak to widać $\mathrm{z}$ jego spuścizny rękopiśmiennej, dość charakterystyczną, upraszczającą i ułatwiającą zadanie metodę. Bardzo sumiennie uwzględnia wszelkie źródła już drukowane, a $\mathrm{z}$ niedrukowanych przede wszystkim tylko łatwo czytelne lub będące już choćby skromnymi opracowaniami. Należą tu diariusze i historie kolegiów, wszelkie katalogi, nekrologi, oficjalne kopiariusze listów ${ }^{4}$.

3 S. Bednarski, Polonica w archiwach jezuickich, „Nauka Polska” 1935, nr 20, s. 142.

4 Tamże. 
Znaczną część dzieła Załęskiego zajmują dzieje poszczególnych kolegiów jezuickich, które Bednarski tak scharakteryzował:

Załęski nie robił z kronik wyciągów, ale od razu, w porządku chronologicznym, streszczał je lub nawet partiami tłumaczył. W ten sposób otrzymywał jakby zrąb historii każdego kolegium, zrąb, który potem uzupełniał ubocznie zebranymi wiadomościami i objaśniał w miarę potrzeby notami. Metoda ta nie dała się zastosować do wszystkich zagadnień, musiał więc wtedy robić właściwe wyciaggi ${ }^{5}$.

W Archiwum Prowincji Polski Południowej Towarzystwa Jezusowego w Krakowie (ATJKr.) pozostała olbrzymia ilość notatek i wyciągów Załęskiego, jednak bez podania źródeł. Nie zostawił też żadnej kartoteki, nie miał swoich współpracowników czy następców. Nic więc dziwnego, że wielkie dzieło Załęskiego nie wpłynęło na pogłębienie studiów o jezuitach. Nadal bezkrytycznie pisano lub też powtarzano za nim informacje bądź z nim bezkrytycznie polemizowano.

Kolejny historyk jezuicki, Stanisław Bednarski ${ }^{6}$, przystępując do pisania na temat źródeł do dziejów zakonu jezuitów, musiał zaczynać pracę od nowa. Po gruntownych studiach nad dziejami kultury i szkolnictwa polskiego, przebadał archiwa i biblioteki krajowe i zagraniczne, sprowadzając do kraju fotokopie najważniejszych zbiorów dotyczących zakonu, w końcu stworzył w Krakowie Bibliotekę Prowincji, do której włączył stare druki z domów zakonnych, powiększane potem własnymi zakupami. Korzystając $z$ tego rozbudowanego warsztatu pracy, mógł stworzyć swoje pomnikowe dzieło na temat jezuickiego szkolnictwa ${ }^{7}$.

Mając już bogate doświadczenie w badaniach nad dziejami zakonu, pozostawil pierwszy, naukowy i ciaggle aktualny przewodnik po archiwach i bibliotekach nie tylko jezuickich, ale i państwowych oraz prywatnych zawierających jezuicką spuściznę ${ }^{8}$.

5 Tamże, s. 143.

6 J. Paszenda, Dziatalnośc naukowa ks. Stanistawa Bednarskiego SJ, „Nasza Przeszłość"1993, t. 80, s. 345-368.

7 S. Bednarski, Upadek i odrodzenie szkót jezuickich w Polsce. Studium z dziejów kultury i szkolnictwa polskiego, Kraków 1933, ss. 537.

8 S. Bednarski, Polonica w archiwach jezuickich, „Nauka Polska” 1935, nr 20, s. $141-167$. 
W części pierwszej Bednarski przedstawił przegląd poloników z centralnego Archiwum Towarzystwa Jezusowego w Rzymie oraz Archiwum Prowincji Małopolskiej (obecnie Polski Południowej) Towarzystwa Jezusowego w Krakowie. W części drugiej dokonał przeglądu poloników jezuickich pod względem rodzaju i zawartości rękopisów. Autor był już w tym czasie doskonale rozeznany w zawartości jezuickiego archiwum rzymskiego i krakowskiego, jednak nie dotarł do wszystkich rękopisów w innych archiwach polskich i zagranicznych. Do wybuchu wojny w 1939 roku Bednarski powiększał ustawicznie zbiory krakowskie, prowadził poszukiwania nowych rękopisów w archiwach i bibliotekach oraz opiekował się młodymi historykami, którzy mieli jego dzieło kontynuować.

Po zakończeniu II wojny światowej jego warsztat objął Jan Poplatek (1903-1955), który pod kierunkiem Bednarskiego już przed wojną wydał pierwszy naukowy żywot św. Andrzeja Boboli oraz kilka niewielkich ale źródłowych prac m.in. o Seminarium Papieskim w Wilnie ${ }^{9}$, był więc do pracy archiwalnej i źródłoznawczej jak najlepiej przygotowany ${ }^{10}$.

Nie mogąc w okresie stalinizmu publikować swoich prac, pisał je i przygotowywał do druku, ale z konieczności wkładał wyłącznie „do biurka”. Dopiero po jego śmierci w 1955 roku można było opublikować kilka jego cennych studiów. Należały do nich m.in. prace o teatrze jezuickim, artystach jezuickich oraz Komisji Edukacji Narodowej ${ }^{11}$.

Kilka dalszych cennych jego studiów, jak obszerny Stownik jezuitów polskich XVI wieku, materiały dotyczące losów jezuitów w czasie II wojny światowej i inne pozostają w maszynopisach.

Drogą Bednarskiego i Poplatka podążył Bronisław Natoński (1914-1989) ${ }^{12}$, który mimo cenzury kompletował, niekiedy prze-

9 J. Poplatek, Btogostawiony Andrzej Bobola Towarzystwa Jezusowego. Życie męczeństwo - kult, Kraków 1936, ss. 332; Tenże, Zarys dziejów Seminarium Papieskiego w Wilnie 1585-1773, „Ateneum Wileńskie” 1930, t. 7, s. 170228. - Toż w osob. odb., Wilno 1930, ss. 113.

10 B. Natoński, Ks. Jan Poplatek T.J. (1903-1955), „Nasza Przeszłość” 1957, t. 5, s. 238-270 i odb., Kraków 1957, ss. 33.

11 J. Poplatek, Studia z dziejórw jezuickiego teatru szkolnego w Polsce, Wrocław 1957, ss. XII + 226; Tenże, Stownik jezuitów artystórw, uzup. i wydał J. Paszenda, Kraków 1972, ss. 298; Tenże, Komisja Edukacji Narodowej. Udziat bylych jezuitórw w pracach Komisji Edukacji Narodowej, uzup. L. Grzebień, Kraków 1973, ss. 512.

12 L. Grzebień, Bronistaw Natoński SJ, „Rocznik Wydziału Filozoficznego Towarzystwa Jezusowego w Krakowie” 1989, Kraków 1990, s. 255-278. 
mytem, w postaci mikrofilmów rękopisy z Archiwum Rzymskiego i innych archiwów europejskich. Opracował gruntowne dziełka o szkolnictwie, teologii polemicznej i stosunkach jezuitów z Uniwersytetem Krakowskim ${ }^{13}$. Swój wysiłek upowszechniania wiedzy skupił jednak głównie na Polskim stowniku biograficznym i fachowej pomocy uczonym (Elżbieta Aleksandrowska, Roman Darowski, Jan Okoń, Ludwik Piechnik, Kazimierz Puchowski) przy tworzeniu syntez naukowych i słowników.

Krakowski zbiór jesuitików pomnażał też Ludwik Grzebień, który częściowo uporządkował zbiory i wydawał prace Poplatka, zainicjował i przygotował do druku kompendium wiedzy o jezuitach polskich ${ }^{14}$, doprowadził do końca publikację Dziennika Jana Wielewickiego ${ }^{15}$ oraz przygotował też z Andrzejem Pawłem Biesiem, Robertem Danielukiem i Markiem Inglotem wydanie dokładnego inwentarza poloników w Archivum Romanum Societatis Iesu (ARSI). Tak przystępny, ale krótki opis Bednarskiego został ostatnio zastąpiony dokładnymi inwentarzami opracowanymi i opublikowanymi ${ }^{16}$.

Z innych autorów zaledwie kilku zajmowało się zachowanymi źródłami do dziejów jezuitów polskich. Były to zresztą niewielkie przyczynki, bo w miarę pełny zestaw rękopisów z tego zakresu znajduje

13 B. Natoński, Szkolnictwo jezuickie w Polsce w dobie kontrreformacji, w: Wiek XVII - Kontrreformacja - Barok, Wrocław 1970, s. 309-337; Tenże, Humanizm jezuicki i teologia pozytywno-kontrowersyjna w XVII i XVIII wieku. Nauczanie i piśmiennictwo, w: Dzieje teologii katolickiej w Polsce, t. 2, cz. 1, red. M. Rechowicz, Lublin 1975, s. 87-219. - Toż w osob. odb., Kraków 2003, ss. 282; Tenże, Jezuici a Uniwersytet Krakowski w XVI w., w: Studia z historii jezuitów, Kraków 1983, s. 173-245. - Toż, Kraków 2002, ss. 142.

14 Encyklopedia wiedzy o jezuitach na ziemiach Polski i Litwy 1564-1995, oprac. L. Grzebień przy współpracy zespołu jezuitów, Kraków 1996, ss. 882. wyd. 2., Kraków 2004, ss. 882.

15 J. Wielewicki, Dziennik spraw domu zakonnego OO. Jezuitów u św. Barbary w Krakowie, t. 5: 1630-1639, Kraków 1999, ss. 596.

16 A.P. Bieś, L. Grzebień, M. Inglot, Polonica w Archiwum Rzymskim Towarzystwa Jezusowego, t. 1: Polonia, Kraków 2002, ss. 430; t. 2: Lituania, Kraków 2003, ss. 372. - A.P. Bieś, R. Danieluk, L. Grzebień, M. Inglot, Polonica w Archiwum Rzymskim Towarzystwa Jezusowego, t. 3: Germania, Kraków 2006, ss. 495; t. 4: Varia, Kraków 2008, ss. 554; t. 5: Russia, Kraków 2008, ss. 345 . 
się w ośrodku krakowskim stworzonym przez Bednarskiego i uzupełnianym przez jego następców ${ }^{17}$.

Materiały krakowskie dotyczą całej dawnej asystencji polskiej, a zatem nie tylko Polski i Litwy, ale także Łotwy, Białorusi czy Ukrainy. Historycy tych krajów często rozpoczynają swoje naukowe poszukiwania od zbiorów krakowskich i chętnie korzystają z tego ośrodka, tym bardziej, że najważniejsze rękopisy dostępne są tu również na nośnikach elektronicznych.

Wszystkie najważniejsze dzieła, jakie ukazały się w Polsce w ostatnich dziesiątkach lat, powstawały w dużym stopniu na podstawie materiałów ośrodka krakowskiego i przy wspólpracy z jego pracownikami. Wystarczy tu wymienić kilka cennych studiów o różnych aspektach działalności zakonu: teatru szkolnego ${ }^{18}$, nauczania filozofii ${ }^{19}$ i matematyki ${ }^{20}$, Ratio studiorum ${ }^{21}$, seminariów duchownych ${ }^{22}$, burs muzycznych ${ }^{23}$ oraz kolegiów szlacheckich ${ }^{24}$.

17 W. Gramatowski, I. Kadulska, Dokumenty polskie w zbiorach Archivum Romanum Societatis Iesu, w: Staropolska kultura rękopisu, red. H. Dziechciańska, Warszawa 1990, s. 163-189; A. Rusnok, Rękopiśmienne źódta do badań nad dziejami jezuitów w zbiorach Ksiqżnicy Cieszyńskiej oraz Archiwum Państwowego w Katowicach - Oddziat w Cieszynie, w: Towarzystwo Jezusowe na Ślqsku Cieszyńskim, red. J. Budniak, K. Mozor, Kraków 2005, s. 249-260.

18 J. Okoń, Dramat i teatr szkolny. Sceny jezuickie XVII wieku, Wrocław 1970, ss. 460; Tenże, Na scenach jezuickich w dawnej Polsce (rodzimośc i europejskość), Warszawa 2006, ss. 247; I. Kadulska, Komedia w polskim teatrze jezuickim XVIII wieku, Wrocław 1993, s. 248; Taż, Ze studiów nad dramatem jezuickim wczesnego oświecenia (1746-1765), Wrocław 1974, ss. 204.

19 R. Darowski, Filozofia w szkotach jezuickich w Polsce w XVI wieku, Kraków 1994, ss. 450; Tenże, Studia z filozofi jezuitów w Polsce w XVII i XVIII wieku, Kraków 1998, ss. 372.

20 B. Lisiak, Nauczanie matematyki w polskich szkotach jezuickich od XVI do XVIII wieku, Kraków 2003, ss. 258.

21 L. Piechnik, Powstanie i rozwój jezuickiej „Ratio studiorum” (1548-1599), Kraków 2003, ss. 264.

22 L. Piechnik, Seminaria diecezjalne w Polsce prowadzone przez jezuitów od XVI do XVIII wieku, Kraków 2001, ss. 282.

23 J. Kochanowicz, Jezuickie bursy muzyczne w Polsce i na Litwie w XVII i XVIII wieku, t. 1: Geneza, organizacja $i$ dziatalnośc jezuickich burs muzycznych, Kraków 2002, ss. 142; Tenże, Jezuickie bursy muzyczne w Polsce i na Litwie w XVII i XVIII wieku, t. 2: Przepisy dotyczace jezuickich burs muzycznych, Kraków 2002, ss. 142.

24 K. Puchowski, Jezuickie kolegia szlacheckie Rzeczypospolitej Obojga Narodów. Studium z dziejórw edukacji elit, Gdańsk 2007, ss. 636. 
$\mathrm{Na}$ podstawie materiałów zgromadzonych w ośrodku krakowskim powstało kilka biografii wybitnych jezuitów. Należą do nich m.in. monografie o Pawle Giżyckim ${ }^{25}$, Adamie Kochańskim ${ }^{26}$, Marcinie Laternie ${ }^{27}$ i Piotrze Skardze ${ }^{28}$.

Podobnie w dużym stopniu na „źródłach krakowskich” oparte zostały monografie o kolegiach jezuickich i ich działalności w Braniewie $^{29}$, Gdańsku ${ }^{30}$, Połocku ${ }^{31}$ i Wilnie ${ }^{32}$.

Ośrodek krakowski zabiegał też o udostępnienie w druku różnego rodzaju źródeł rękopiśmiennych. W ostatnim okresie ukazał się więc wspomniany już cenny Dziennik spraw domu zakonnego OO. Jezuitów u św. Barbary w Krakowie Jana Wielewickiego i Kronika jezuitów poznańskich ${ }^{33}$ oraz korespondencja wybitnego matematyka Adama Kochańskiego ${ }^{34}$.

W ośrodku krakowskim zaczęto też interesować się jezuitami śląskimi, którzy należeli do prowincji czeskiej, a w drugiej połowie XVIII w. utworzyli własną prowincję zakonną. Ich główne archiwum

25 A. Betlej, Pawet Giżycki SJ. Architekt polski XVIII wieku, Kraków 2003, ss. 398.

26 B. Lisiak, Adam Adamandy Kochañski (1631-1700). Studium z dziejów filozofi i nauki w Polsce w XVII wieku, Kraków 2005, ss. 525.

27 S. Cieślak, Marcin Laterna SJ (1552-1598), dziatacz kontrreformacyjny, Kraków 2003, ss. 400.

28 J. Tazbir, Piotr Skarga, szermierz kontrreformacji, Warszawa 1978, ss. 344; wyd. 2. Warszawa 1983, ss. 288.

29 M. Inglot, L. Grzebień, Uczniowie - Sodalisi Gimnazjum Jezuitów w Brunsberdze (Braniewie), 1579-1623, Kraków 1998, ss. 346.

30 S. Kościelak, Jezuici w Gdańsku od drugiej potowy XVI do końca XVIII wieku, Gdańsk 2003, ss. 368.

31 I. Kadulska, Akademia Potocka. Ośrodek kultury na Kresach, 1812-1820, Gdańsk 2004, ss. 308.

32 L. Piechnik, Dzieje Akademii Wileńskiej, t. 1: Poczatki Akademii Wileńskiej (1569-1600), Rzym 1984, ss. 263; Tenże, Dzieje Akademii Wileńskiej, t. 2: Rozkwit Akademii Wilenskiej w latach 1600-1655, Rzym 1983, ss. 313; Tenże, Dzieje Akademii Wileñskiej, t. 3: Próby odnowy Akademii Wileñskiej po klęskach Potopu i okres kryzysu 1655-1730, Rzym 1987, ss. 261; Tenże, Dzieje Akademii Wileñskiej, t. 4: Odrodzenie Akademii Wileńskiej 1730-1773, Rzym 1990, ss. 3074.

33 Kronika jezuitów poznañskich (mtodsza), t. 1: 1570-1653, oprac. L. Grzebień, J. Wiesiołowski, Poznań 2004, ss. 548.

34 Korespondencja Adama Adamandego Kochańskiego SJ (1657-1699), oprac. B. Lisiak przy współpracy L. Grzebienia, Kraków 2005, ss. 475. 
znajdowało się w Kłodzku i zachowało się do XX wieku w dobrym stanie. Później część rękopisów przeniesiono do archiwów państwowych i kościelnych we Wrocławiu, ale większość pozostała zaniedbana na miejscu w Kłodzku i dopiero pod koniec XX w. została przeniesiona do archiwum prowincji w Krakowie. Jest to największy zbiór jesuitików, jaki zachował się w jednym miejscu na terenie naszego kraju. Zbiór ten jest ciągle porządkowany i wpłynie zapewne na zainteresowanie nie tylko jezuitami kłodzkimi, ale też dziejami jezuitów śląskich ${ }^{35}$.

\section{Przegląd najważniejszych rękopisów}

Dawne archiwa jezuickie posiadały trzystopniową strukturę, znajdowały się we wszystkich domach zakonnych (kolegiach, rezydencjach i stacjach misyjnych) w prowincji (siedzibie prowincjała), a wreszcie w Rzymie, przy zarządzie centralnym zakonu. Większość dokumentów tworzona była równocześnie $\mathrm{w}$ trzech egzemplarzach i przechowywana w trzech miejscach: $w$ archiwum domowym, prowincjalnym i centralnym. Ta praktyka miała ogromne znaczenie dla zachowania się źródeł mimo kasaty zakonu i różnych klęsk żywiołowych. Ordynacje zakonne przewidywały prowadzenie na terenie placówki ok. 40 różnych ksiąg sprawozdawczych dotyczących stanu personalnego placówki, historii, administracji domu, kościoła, szkól, burs, stowarzyszeń i majątków. Odrębne sprawozdania dotyczące całej prowincji zakonnej przygotowywał prowincjał.

Archivum Romanum Societatis Iesu (ARSI) - Archiwum Rzymskie (centralne) Towarzystwa Jezusowego jest archiwum głównym zakonu znajdującym się przy zarządzie centralnym zakonu (obecnie: Rzym, Borgo S. Spirito 4), gromadzącym, porządkującym i udostępniającym podstawowe dokumenty z terenu całego świata. Główny zrąb ARSI stanowi dokumentacja osobowa (katalogi roczne i trzyletnie, śluby, nominacje, nekrologi), historyczna (roczniki i historie kolegiów) i majątkowa (akta fundacyjne, darowizny, testamenty, wyroki sądowe) oraz korespondencja oficjalna, półoficjalna i prywatna (generała zakonu, kardynałów, biskupów, królów, książąt, magnatów,

35 Zob. Z. Lec, Jezuici w Ktodzku (1597-1776). Katalog osób i urzędów, materiaty źródtowe, literatura, Szczecin 2013, ss. 232. 
szlachty, duchowieństwa, miast, prowincji zakonnych, domów, przełożonych zakonnych wszystkich szczebli). Osobny dział stanowiły akta kongregacji generalnych, kongregacji prokuratorów i kongregacji prowincji. Polonica występują w dziale Asystencji Niemieckiej (Germania) i obejmują osobno wydzielone poddziały: Provincia Poloniae (Prowincja Polska) obejmująca 94 tomów i Provincia Lithuaniae (Prowincja Litewska) obejmująca 67 tomów. W obu poddziałach układ dokumentów jest podobny: listy, katalogi trzyletnie, historie, litterae annuae, katalogi roczne, nekrologi i wreszcie drobne zbiory różnych dokumentów. Wiele listów z Polski znajduje się też w dziale Germania (t. 104-188).

Osobny dział w archiwum stanowi Fondo Gesuitico (FG), obejmujące wielki ilościowo zbiór dokumentów odnoszących się do stosunków zakonu z rzymskimi kongregacjami i trybunałami. Jest tu dużo dokumentów dotyczących sporów jezuitów polskich z Akademią Krakowską, pijarami, duchowieństwem diecezjalnym oraz aktów fundacyjnych i zapisów majątkowych.

Archiwa dawnych prowincji polskich oraz archiwa kolegiów i rezydencji polskich zostały po kasacie zakonu w 1773 roku w zdecydowanej większości zniszczone, a tylko niektóre rękopisy rozproszone i znajdują się dziś w archiwach i bibliotekach państwowych i różnych archiwach kościelnych.

Bednarski przedstawił w swoim przeglądzie poloników w archiwach stan wiedzy $z$ lat 30 . XX wieku. Niemal cały ten opisany przez niego zasób został w postaci fotokopii i mikrofilmów, a także płyt CD zgromadzony w ośrodku krakowskim. Ponadto udało się odkryć wiele nowych rękopisów, o których Bednarski nie wiedział. Według schematu zastosowanego przez Bednarskiego omówimy więc wszystkie działy, a zarazem podamy ich wykorzystanie w pracach naukowych.

1. Katalog os ob owy roczny. Katalog osobowy roczny ( $C a-$ talogus personarum brevis), czyli wykaz osób należących w określonym czasie do zakonu jezuitów. Katalog ten podawał na początku nazwiska prowincjała i jego sekretarza, potem wyliczał wszystkie domy zakonne prowincji ułożone kolejno według dat ich powstania, a od XVII w. w porządku alfabetycznym kolegiów, którym podporządkowane były rezydencje i stacje misyjne. W ramach domów umieszczano wykaz osób, najpierw nazwisko przełożonego, potem nazwiska 
księży (patres) w porządku alfabetycznym imion, nazwiska nauczycieli (magistri), którzy nie byli jeszcze kapłanami, nazwiska studiującej młodzieży zakonnej (scholastici), wreszcie nazwiska braci zakonnych (fratres coadiutores). Do katalogu dodawano wszelkie zmiany, jakie nastąpiły po sporządzeniu katalogu poprzedniego, a więc wykaz osób wstępujących do zakonu, zmarłych i opuszczających zakon. Informacje miały być krótkie i treściwe. Katalogi roczne stanowią podstawowe źródło do ustalenia chronologii życia i prac jezuitów, a zarazem jedno z najważniejszych do historii kolegiów, do poznania rodzaju prac w nich podejmowanych, typu szkół itd. Są koniecznym uzupełnieniem historii kolegiów, w których zwykle nie podawano nazwisk, lecz same zdarzenia. Pozwalają zidentyfikować wielu anonimowych twórców dzieł sztuki i autorów anonimowych dzieł literackich. Katalogi roczne były sporządzane przynajmniej w dwóch egzemplarzach, jeden wysyłano do Rzymu, drugi pozostawał w Archiwum Prowincji.

Katalogi $\mathrm{z}$ tego ostatniego archiwum $\mathrm{w}$ większości zaginęły w chwili kasaty zakonu, przechowywane zaś w Archiwum Generalnym zakonu ocalały niemal w komplecie. Od 1717 roku drukowano katalogi roczne w Prowincji Polskiej, a od roku 1725 również w Prowincji Litewskiej. Katalogi roczne sprowadzone przez Bednarskiego zostały w okresie powojennym uzupełnione i znajdują się w postaci fotokopii prawie w komplecie, stanowiąc obecnie główne źródło, na którym opierają się historycy krajowi i zagraniczni piszący na temat jezuitów.

W Bibliotece Jagiellońskiej (rękopisy 2450, 2558) zachowały się dwa katalogi prywatne dla prowincji polskiej, pisane przez jezuitów na własny użytek, a obejmujące chronologiczny spis członków prowincji z podaniem daty urodzenia, wstąpienia do zakonu i śmierci lub dymisji z zakonu. Obejmują lata 1700-1753. Stanowią one uzupełnienie katalogów rocznych, obejmują również te osoby, które wstąpiły do zakonu i wkrótce go opuściły, zanim został sporządzony katalog roczny $^{36}$.

2. Katalog osobowy trzyletni. Oprócz katalogów rocznych należało od 1578 roku sporządzać co trzy lata osobny katalog informacyjny o członkach zakonu i wysyłać go do Rzymu przez promości"1916-1920, nr 5, s. 118-120. 
kuratora prowincji. Katalog zwany „pierwszym” miał zawierać zwyczajne informacje o każdym z członków zakonu (numer porządkowy, imię, nazwisko, miejsce pochodzenia, wiek, stan zdrowia, data wstąpienia do zakonu, ślubów, studia przed wstąpieniem, studia i funkcje w zakonie, stopień naukowy względnie zawód, rodzaj i data ostatnich ślubów). Katalog trzyletni „drugi” zawierał uwagi sekretne o każdej osobie, nie podawał nazwisk osób, ale pod ich numerem $\mathrm{z}$ katalogu pierwszego zawierał charakterystykę osób i ich kwalifikacji według następującego kwestionariusza: zdolności umysłowe (ingenium), rozsądek (iudicium), roztropność (prudentia), doświadczenie życiowe (experientia rerum), postęp $\mathrm{w}$ studiach, naturalne cechy charakteru (naturalis complexio), zdolności, ich kierunek i przydatność do prac zakonu. Katalog trzyletni „trzeci” podawał krótką charakterystykę stanu majątkowego i gospodarczego domów zakonnych. Podawano ogólną sumę dochodów, rozchodów i długów. Dorzucano niekiedy wiadomości o stanie majątków i ich rentowności. Informacje te miano spisywać starannie, po namyśle, $\mathrm{z}$ wykluczeniem prywatnych względów uczuciowych, szczerze i krótko. Katalogi trzyletnie nigdy nie były drukowane.

W ARSI zachowały się niemal wszystkie katalogi trzyletnie dla prowincji polskiej, wielkopolskiej, małopolskiej i litewskiej od roku 1571 do 1770 (Lit. 6-32; Pol. 6-42). Dla prowincji mazowieckiej zachował się jedynie katalog z roku 1766 (Lit. 32a), nie ma natomiast wiadomości o katalogach z lat 1761, 1764 i 1770.

3. Nekrologi. Po śmierci każdego jezuity w domu, w którym umarł, spisywano krótki jego życiorys w osobnej księdze nekrologów i co trzy lata sporządzano kopie dla Archiwum Prowincji i centralnego archiwum w Rzymie. Wartość nekrologów jest niejednakowa i względna. Czasem sporządzano je bardzo sumiennie, czasem zbyt pobieżnie, ograniczając się do ogólników. $Z$ nekrologów należy więc korzystać bardzo ostrożnie i potwierdzenia podanych wiadomości należy szukać $w$ innych źródłach. Nekrologi polskich jezuitów zachowały się w większości w ARSI (Pol. 68, 69, 86, 89; Lit. 55, 6165). Można je napotkać także w historiach poszczególnych kolegiów (m.in. Pol. 52; Lit. 38). Zachowały się też niektóre księgi nekrologów poszczególnych domów zakonnych: Dyneburga za lata 1758-1790 (ATJKr. 1927 II), Domu Profesów w Krakowie za lata 1584-1646 (Bibl. Jag. 2692), Mohylewa za lata 1673-1809 (ATJKr. 340), Po- 
locka za lata 1749-1815 (ATJKr. 350) i kolegium w Wilnie za lata 1669-1773 (Bibl. KUL 335).

4. In for $\mathrm{m}$ a cj e. Informacje o osobach proponowanych na różne urzędy w zakonie (Informationes ad gubernandum) obejmowały podstawowe dane o osobie, jej doświadczeniu w zarządzaniu oraz o cechach charakteru. Kilka z nich zachowało się w Bibliotece Narodowej w Wiedniu, a tylko jeden na terenie Polski ${ }^{37}$.

$\mathrm{W}$ ośrodku akademickim $\mathrm{w}$ Wilnie powstały też informacje o osobach pracujących $\mathrm{w}$ Akademii ${ }^{38}$ oraz informacje o wynikach egzaminów z zakresu filozofii i teologii ${ }^{39}$. Cennym informatorem o stopniach naukowych nadanych w Akademii Wileńskiej jest kodeks Laureae Academicae, wydany w 1997 roku w Wilnie ${ }^{40}$.

Do rękopisów biograficznych należy też zaliczyć księgę metryk kandydatów do zakonu z nowicjatu braniewskiego z lat 1569-1574, a więc pierwszego pokolenia jezuitów polskich, wydaną ostatnio drukiem $^{41}$. $Z$ nowicjatu krakowskiego zachował się zaś zbiór kopii metryk z lat 1709-1773, a więc dotyczących większości jezuitów prowincji polskiej działających w XVIII w. ${ }^{42}$.

Dla prowincji litewskiej cenny jest olbrzymi rękopis historyka Jana Poszakowskiego De viris illustribus Prov. Lituaniae, zachowany w archiwum jezuitów w Krakowie (ATJKr. 1536), który, mimo popularnego charakteru, posiada wiele cennych i szczegółowych informacji dotyczących jezuitów głównie z XVIII w., jakich nie znajdziemy w innych źródłach.

37 Informationes ad gubernandum Provinciae Poloniae Societatis Iesu, 1700, 1726, 1730, 1734, Nationalbibliothek Wien, rkps 12362 - 12 365; Liber informationum ad gubernandum A.D. 1749, kk. 117. Bibl. Morsztynów, rkps 28 .

38 Informatio de personis Collegii Academici Vilnensis conscripta anno 1773, Bibl. Uniw. Wil. F2-DC7.

39 Examina theologorum et philosophorum in Collegio Vilnensi, Akademia, 16881773, Wilno, Bibl. Wróblewskich, rkps 145 (obecnie: MAB, F9-145).

40 Akademijos laurai. Laureae academicae, Vilnius 1997, ss. 411.

41 „Examina novitiorum” (Egzaminy nowicjuszów) jezuitów z Branierwa z lat 1569-1574, wstęp i oprac. J. Eukaszewska-Haberkowa, Kraków 2012, ss. 236.

42 Liber metricae novitiorum Soc. Iesu, Cracoviae anno 1709 comparatus (ad 1773), k. 1-120. Bibl. Ossol. rkps 100. 
5. Kor esponde n cja. Bednarski dość szczegółowo opisał zachowaną w ARSI korespondencję zarówno jezuitów, jak i innych osób duchownych i świeckich, dzieląc ją na trzy działy:

a) korespondencja poufna, oficjalna i prywatna;

b) listy generałów do jezuitów polskich, okólniki;

c) korespondencja wzajemna generałów z Polską, z wyłączeniem jezuitów.

Opis Bednarskiego pozostaje nadal aktualny, a dokładny inwentarz listów z ARSI został zamieszczony ostatnio w publikacji Polonica w Archiwum Rzymskim Towarzystwa Jezusowego. Zbiór listów jest zachowany w większości i dostępny w Krakowie w postaci mikrofilmów i fotokopii.

Korespondencja jezuitów w obrębie prowincji. Prawie zupełnie zaginęła korespondencja prowincjałów z przełożonymi domów i ich podwładnymi i na odwrót, przyjacielska korespondencja jezuitów między sobą, między jezuitami i ich rodzinami, w końcu korespondencja między jezuitami a szlachtą i magnaterią oraz duchowieństwem diecezjalnym. Po kilkaset listów jezuitów polskich i litewskich przechowują jedynie Archiwum Radziwiłłów (AGAD w Warszawie), Biblioteka Narodowa w Warszawie (listy do Józefa Andrzeja Załuskiego) oraz Archiwum Narodowe w Krakowie w Tekach Schneidera na Wawelu.

6. Historie kolegiów. W każdym domu zakonnym prowadzono diariusz, w którym wyznaczony historyk, zwykle profesor wymowy, dzień po dniu spisywał zdarzenia tego dnia, zwyczajne i nadzwyczajne. Ponieważ jezuici brali udział w życiu społeczeństwa i narodu, przeto interesowały ich sprawy nie tylko zakonne, ale też ogólnonarodowe, regionalne i miejscowe. Diariusze zapowiadające $z$ tytułu dzieje jednego domu w rzeczywistości wykraczały poza jego mury. Większość diariuszy zaginęła. Bednarski przybliżył kilka $\mathrm{z}$ nich.

Z zachowanych najcenniejszym jest kilkutomowy Dziennik spraw domu zakonnego OO. Jezuitów u Śr. Barbary w Krakowie Jana Wielewickiego (t. 1-4, Kraków 1881-1899), obejmujący lata 1579-1639. Ostatni tom piąty obejmujący lata 1630-1639 został opublikowany dopiero w 1999 roku.

Z nieznanych Bednarskiemu i odkrytych później diariuszy należy wymienić kilka innych. Za wiek XVI zachowały się jedynie frag- 
menty bardzo dokładnego diariusza poznańskiego z lat 1569-1606 (Arch. Diec. Warsz. 440).Za okres późniejszy zachowały się diariusze domów zakonnych w Mitawie 1691-1709 (Arch. Łotewskie w Rydze), Tylży 1690-1783 (Bibl. Sem. Olsztyn 129-131), dla rezydencji w Piekarach Śląskich, należących do prowincji czeskiej, ale związanych z Polską, zachowały się diariusze $\mathrm{z}$ lat 1678-1696 i 1711-1750 (Arch. Kościoła Mariackiego w Krakowie, ATJKr. i Arch. Parafialne w Piekarach). Wszystkie te diariusze są dostępne w postaci mikrofilmów w ośrodku krakowskim.

Litterae annuae zawierają zbiór wiadomości o działalności poszczególnych domów jezuickich. Posiadały charakter sprawozdawczy, zawierały jednak głównie wiadomości pozytywne i budujące. Po Bednarskim uzupełniono zbiory krakowskie o wszystkie znane rękopisy tego typu, jak i tomy Annuae drukowane w latach 1581-1616 dla całego zakonu.

Historia domu (Historia domus). Historie domów zakonnych pojawiły się jako źródło historyczne w początkach XVII w. oprócz istniejących już Litterae annuae. Obejmowały wiadomości o dziejach placówki, ważniejszych zdarzeniach, sprawach majątkowych oraz sprawach regionalnych związanych z życiem domu zakonnego. W odróżnieniu od Litterae annuae zawierają więcej konkretnych wiadomości o działalności poszczególnych jezuitów, określają stan materialny placówki, opisują wydarzenia polityczne, społeczne i kulturalne związane $\mathrm{z}$ domem. Tworzone były w poszczególnych domach, przeważnie na podstawie diariuszów. Streszczenia Historii domu, podobnie zresztą jak Litterae annuae, były co trzy lata przesyłane do Rzymu. Przechowuje je dziś ARSI (Pol. 50-60, 6566; Lit. 38-51, 55). Niektóre roczniki historii zachowały się także $\mathrm{w}$ archiwach i bibliotekach polskich.

Historie nieznane Bednarskiemu zachowały się również dla domów:

- Braniewo 1643-1772 (Muz. Warm.w Olsztynie);

- Dyneburg 1758-1790 (ATJKr. 1027 II);

- Krosno 1720-1772 (Bibl. Narodowa, Wiedeń 12 417);

- Królewiec 1692-1740 (Arch. Diec. w Olsztynie H 204);

- Malbork 1647-1744 (Arch. Diec. w Olsztynie H 11);

- Nastasów 1692-1771 (Bibl. Narodowa, Wiedeń 8248);

- Rożniatów 1669-1733 (Bibl. Narodowa, Wiedeń 11 989). 
Historię kolegium w Gdańsku za lata $1585-1642^{43}$ i w Wałczu za lata $1618-1773^{44}$ wydano drukiem na terenie Niemiec, choć ich rękopisy zachowały się na terenie Polski.

Zachowały się również nieliczne historie kościołów jezuickich, m.in. w Jarosławiu 1570-1724 (Bibl. Ossol. 9539).

7. Dokumenty prawne i gospodarcze. Fundacje i zapisy majątkowe zachowały się zarówno w ARSI, FG, jak i w licznych archiwach i bibliotekach polskich. Wiele $\mathrm{z}$ nich przechowują Teki Schneidra w Oddziale I Archiwum Narodowego w Krakowie i archiwum jezuitów w Krakowie.

Rezygnacje (Resignationes) to sprawozdania ze stanu domu, sporządzane przez ustępującego $\mathrm{z}$ urzędu rektora kolegium, superiora rezydencji lub domu misyjnego. Składając urząd w ręce następcy, rektorzy i superiorzy przedstawiali stan majątkowy domu i zmiany dokonane podczas ostatniej kadencji. Rezygnacje ukazują stan kolegium i kościoła, zawierają inwentarze kościelne, domowe i biblioteczne, opisują gospodarkę w folwarkach jezuickich. Stanowią dziś bardzo ważne źródło do poznania głównie gospodarczego stanu placówki.

Zachowały się tylko nieliczne rezygnacje dla kolegium w Krośnie za lata 1671-1756 (Bibl. Ossol. 9550), Lwowie za lata 1696-1764 (Bibl. PAN w Krakowie 1958), Mohylewie za lata 1673-1809 (ATJKr. 340), Samborze za lata 1706-1747 (Bibl. PAN w Krakowie 886) i Stanisławowie za lata 1715-1728 (Bibl. PAN w Krakowie 893). Kilkanaście rezygnacji dla kolegiów prowincji polskiej znajduje się w Tekach Schneidra.

Do spisywania rezygnacji zobowiązani byli też prefekci kościołów, burs i innych dzieł czynnych w obrębie domu zakonnego. Księga rezygnacji prefekta kościoła NMP w Jarosławiu za lata 1710-1768 znajduje się w Bibl. PAN w Krakowie (rkps 880), a księga rezygnacji bursy muzyków w Krakowie za lata 1737-1768 w Bibl. Jag. (rkps 2431).

Lustracje. Po kasacie zakonu komisje lustracyjne przeprowadziły inwentaryzację całego majątku pojezuickiego w domach zakonnych pozostających po pierwszym rozbiorze $\mathrm{w}$ granicach państwa. Lustracje zawierają dokładny opis przejętego majątku, a więc budynków, kościołów, bibliotek i majątków ziemskich. Dotąd zachowały

43 Historia Residentiae Gedanensis Societatis Jesu ab anno 1585, red. R. Stachnik, Köln-Wien 1986, ss. XVIII + 204.

44 Historia Residentiae Walcensis Societatis Jesu ab anno 1618, Geschichte der Jesuitenresidenz in Watcz, Köln 1967, ss. XII + 326. 
się Lustracje dla kolegium w Krakowie (Bibl. PAN w Krakowie 1153), Nieświeżu (ATJKr. 302), Płocku (Bibl. PAN w Krakowie 1156), Słucku (Warszawa, AGAD, ARadz. VIII 519), Wilnie (Bibl. Uniw. Wil. F2-DC6).

Przed 1939 rokiem AGAD przechowywało Lustracje kolegium w Sandomierzu (rkps 18), Krakowie (rkps 16 i 52), Łęczycy (rkps 18), Rawie (rkps 15). Biblioteka Uniwersytetu Warszawskiego posiadała lustracje kolegium w Lublinie (Fol. 4. 25) i Warszawie (Fol. 6. 2. 23). Archiwum Oświecenia w Warszawie posiadało zaś lustracje kolegium z Łomży i Poznaniu. Większość z nich zaginęła w czasie II wojny światowej. Kilka Lustracji z terenów Litwy znajduje się prawdopodobnie w archiwach moskiewskich.

8. Rę ko pisy bibliote c zne. Bednarski wyliczył tylko ogólnie rękopisy - „wykłady i dzieła z zakresu teologii, filozofii, matematyki, astronomii retoryki, gramatyki, programy i katalogi szkolne, utwory poetyczne, kaznodziejskie, dramaty i komedie szkolne, dzieła ascetyczne, żywoty świętych i świątobliwych osób, panegiryki, wreszcie wszelkiego rodzaju Silvae". Przechowywane były głównie w bibliotekach świeckich.

Olbrzymi dział rękopisów bibliotecznych jest rozrzucony w licznych archiwach i bibliotekach państwowych, ale szczególnie kościelnych. Ośrodek krakowski prowadzi jedynie ich inwentaryzację. Należą do nich szczególnie liczne rękopisy szkolne z teologii, filozofii, matematyki, retoryki i poetyki, które świadczą o aktywności i poziomie poszczególnych szkól jezuickich. $Z$ racji ich wielości rzadko stanowily one przedmiot badań naukowych.

Inaczej przedstawia się sprawa rękopisów teatralnych, którymi od lat zajmowało się wielu historyków i zostały one przebadane i opisane przez Jerzego Axera, Jana Okonia, Irenę Kadulską $\mathrm{i}$ innych.

W szkołach ważną rolę wychowawczą spełniały studenckie Sodalicje Mariańskie, które istniały we wszystkich szkołach jezuickich w Polsce. W zbiorach polskich zachowały się katalogi sodalisów dla Braniewa, Kłodzka, Krakowa i Nowogródka. Bursy ubogich (bursae pauperum), przeznaczone głównie (choć nie wyłącznie) dla ubogiej, zwłaszcza mieszczańskiej młodzieży uczącej się śpiewu i muzyki, posiadają swoje spisy muzyków i inwentarze dla kolegiów w Krakowie i Krośnie. 
$\mathrm{Z}$ dziedziny życia duchowego zachowało się również bardzo wiele rękopisów ascetycznych, $\mathrm{w}$ tym nauk rekolekcyjnych, przeznaczonych dla formacji jezuitów, sióstr zakonnych, a także świeckich. Interesujące są np. rękopisy ascetyczne Kaspra Drużbickiego z XVII w., zachowane w archiwum jezuitów w Krakowie. Równie wiele istnieje rękopisów kazań, zarówno niedzielnych, jak i świątecznych. Podobnie zachowało się wiele utworów panegirycznych. Szczególnie bogate są w nie biblioteki świeckie.

Akta gospodarcze, księgi rachunkowe majątków, kościołów, kolegiów czy browarów, niekiedy wielotomowe, są przeważnie mało przebadane, a tym samym sprawy gospodarcze zakonu stanowią ciągle mało znany odcinek jego działalności.

Apteki zaś istniejące przy kolegiach zakonnych nie posiadają prawie żadnej, poza nieliczną korespondencją, dokumentacji.

W końcu dział Varia obejmuje różne rękopisy osobiste, zawierające Silva rerum poszczególnych jezuitów o różnorodnej treści i wartości. Przykładem może być w tym zakresie zbiór Michała Jurkowskiego z XVIII w., który doczekał się nawet kilku studiów i przedruków ${ }^{45}$.

9. Architektura i sztuka. Informacje dotyczące architektury i sztuki można znaleźć zarówno w katalogach osobowych, historiach domów zakonnych, luźnych planach budowli zachowanych m.in. w ARSI i Paryżu, jak i w rękopisach osobowych. Ten dział został wystarczająco dobrze opracowany przez historyka sztuki Jerzego Paszendę w pięciotomowym zbiorze studiów ${ }^{46}$.

Kiedy w latach 30. XX w. Bednarski przystępował do tworzenia jezuickiej Biblioteki Prowincji i gromadzenia w postaci fotokopii dokumentacji na temat najstarszych dziejów jezuickich w Polsce, nie przewidywał zapewne, że jego inicjatywa, przemyślane plany pozostawione na piśmie, w końcu dobre fundamenty położone pod wymarzony ośrodek naukowy, dadzą tak znaczące rezultaty. Jego też pamięci należy poświęcić ten skromny szkic historyczny.

Zob. S. Obirek, Michat Jurkowski SJ. Autor „Historyj swieżych i niezwyczajnych", Kraków 1996, ss. 46.

46 J. Paszenda, Budowle jezuickie w Polsce XVI-XVIII w., t. 1-5, Kraków 19992013. 
Akademijos laurai. Laureae academicae, Vilniaus Universiteto Leidykla, Vilnius 1997.

Bednarski S., Polonica w archiwach jezuickich, „Nauka Polska” 1935, nr 20.

Bednarski S., Upadek i odrodzenie szkół jezuickich w Polsce. Studium z dziejów kultury i szkolnictwa polskiego, Wydawnictwo Księży Jezuitów, Kraków 1933.

Betlej A., Paweł Giżycki SJ. Architekt polski XVIII wieku, Towarzystwo Naukowe „Societas Vistulana", Kraków 2003.

Bieś A.P., L. Grzebień, M. Inglot, Polonica w Archiwum Rzymskim Towarzystwa Jezusowego, t. 1: Polonia, Wyższa Szkoła Filozoficzno-Pedagogiczna „Ignatianum” - Wydawnictwo WAM, Kraków 2002.

Bieś A.P., L. Grzebień, M. Inglot, Polonica w Archiwum Rzymskim Towarzystwa Jezusowego, t. 2: Lituania, Wyższa Szkoła Filozoficzno-Pedagogiczna "Ignatianum" - Wydawnictwo WAM, Kraków 2003.

Bieś A.P., R. Danieluk, L. Grzebień, M. Inglot, Polonica w Archiwum Rzymskim Towarzystwa Jezusowego, t. 3: Germania, Wyższa Szkoła Filozoficzno-Pedagogiczna „Ignatianum” - Wydawnictwo WAM, Kraków 2006.

Bieś A.P., R. Danieluk, L. Grzebień, M. Inglot, Polonica w Archiwum Rzymskim Towarzystwa Jezusowego, t. 4: Varia; t. 5: Russia, Wyższa Szkoła Filozoficzno-Pedagogiczna "Ignatianum" - Wydawnictwo WAM, Kraków 2008.

Brzqkalski J., Dwusetna rocznica katalogu polskich jezuitów, „Nasze Wiadomości” 1916-1920, nr 5.

Cieślak S., Marcin Laterna SJ (1552-1598), działacz kontrreformacyiny, Wyższa Szkoła Filozoficzno-Pedagogiczna „Ignatianum" - Wydawnictwo WAM, Kraków 2003.

Darowski R., Filozofia w szkołach jezuickich w Polsce w XVI wieku, Wydział Filozoficzny Towarzystwa Jezusowego, Kraków 1994.

Darowski R., Studia z filozofii jezuitów w Polsce w XVII i XVIII wieku, Wydział Filozoficzny Towarzystwa Jezusowego, Kraków 1998.

Encyklopedia wiedzy o jezuitach na ziemiach Polski i Litwy 1564-1995, oprac. L. Grzebień przy współpracy zespołu jezuitów, Wydział Filozoficzny Towarzystwa Jezusowego - Instytut Kultury Religijnej - Wydawnictwo WAM, Kraków 1996, [wyd. 2., Kraków 2004].

„Examina novitiorum" (Egzaminy nowicjuszów) jezuitów z Braniewa z lat 1569-1574, wstęp i oprac. J. Kukaszewska-Haberkowa, Akademia Ignatianum - Wydawnictwo WAM, Kraków 2012.

Examina theologorum et philosophorum in Collegio Vilnensi, Akademia, 1688-1773, Wilno, Bibl. Wróblewskich, rkps 145 [obecnie: MAB, F9-145].

Gramatowski W., I. Kadulska, Dokumenty polskie w zbiorach Archivum Romanum Societatis lesu, w: Staropolska kultura rękopisu, red. H. Dziechciańska, Instytut Badań Literackich PAN, Warszawa 1990.

Grzebień L., Bronisław Natoński SJ, „Rocznik Wydziału Filozoficznego Towarzystwa Jezusowego w Krakowie" 1989, Kraków 1990. 
Historia Residentiae Gedanensis Societatis Jesu ab anno 1585, red. R. Stachnik, Böhlau Verlag, Köln-Wien 1986.

Historia Residentiae Walcensis Societatis Jesu ab anno 1618, Geschichte der Jesuitenresidenz in Wałcz, Max Rohwerder, Köln 1967.

Informatio de personis Collegii Academici Vilnensis conscripta anno 1773, Bibl. Uniw. Wil. F2-DC7.

Informationes ad gubernandum Provinciae Poloniae Societatis lesu, 1700, 1726, 1730, 1734, Nationalbibliothek Wien, rkps 12362 - 12365.

Inglot M., L. Grzebień, Uczniowie - Sodalisi Gimnazjum Jezuitów w Brunsberdze (Braniewie), 1579-1623, Wyższa Szkoła Filozoficzno-Pedagogiczna "Ignatianum" - Wydawnictwo WAM, Kraków 1998.

Kadulska I., Akademia Połocka. Ośrodek kultury na Kresach, 1812-1820, Wydawnictwo UG, Gdańsk 2004.

Kadulska I., Komedia w polskim teatrze jezuickim XVIII wieku, Zakład Narodowy im. Ossolińskich, Wrocław 1993.

Kadulska I., Ze studiów nad dramatem jezuickim wczesnego oświecenia (1746-1765), Zakład Narodowy im. Ossolińskich, Wrocław 1974.

Kochanowicz J., Jezuickie bursy muzyczne w Polsce i na Liwie w XVII i XVIII wieku, t. 1: Geneza, organizacja i działalność jezuickich burs muzycznych, Wyższa Szkoła Filozoficzno-Pedagogiczna „Ignatianum" - Wydawnictwo WAM, Kraków 2002.

Kochanowicz J., Jezuickie bursy muzyczne w Polsce i na Litwie w XVII i XVIII wieku, t. 2: Przepisy dotyczqce jezuickich burs muzycznych, Wyższa Szkoła Filozoficzno-Pedagogiczna "Ignatianum" - Wydawnictwo WAM, Kraków 2002.

Korespondencja Adama Adamandego Kochańskiego SJ (1657-1699), oprac. B. Lisiak przy współpracy L. Grzebienia, Wyższa Szkoła Filozoficzno-Pedagogiczna „Ignatianum” - Wydawnictwo WAM, Kraków 2005.

Kościelak S., Jezuici w Gdańsku od drugiei połowy XVI do końca XVIII wieku, Wydawnictwo WAM - Gdańskie Towarzystwo Naukowe, Gdańsk 2003.

Kronika jezuitów poznańskich (młodsza), t. 1: 1570-1653, oprac. L. Grzebień, J. Wiesiołowski, Wydawnictwo Miejskie, Poznań 2004.

Lec Z., Jezuici w Kłodzku (1597-1776). Katalog osób i urzędów, materiały źródłowe, literałura, Katedra Historii Kościoła Uniwersytetu Szczecińskiego, Szczecin 2013.

Liber informationum ad gubernandum A.D. 1749, kk. 117. Bibl. Morsztynów, rkps 28.

Liber metricae novitiorum Soc. lesu, Cracoviae anno 1709 comparatus (ad 1773), k. 1-120, Bibl. Ossol., rkps 100.

Lisiak B., Adam Adamandy Kochański (1631-1700). Studium z dziejów filozofii i nauki w Polsce w XVII wieku, Wyższa Szkoła Filozoficzno-Pedagogiczna "Ignatianum" - Wydawnictwo WAM, Kraków 2005.

Lisiak B., Nauczanie matematyki w polskich szkołach jezuickich od XVI do XVIII wieku, Wyższa Szkoła Filozoficzno-Pedagogiczna "Ignatianum" - Wydawnictwo WAM, Kraków 2003. 
Natoński B., Humanizm jezuicki i teologia pozyływno-kontrowersyjna w XVII i XVIII wieku. Nauczanie i piśmiennictwo, w: Dzieje teologii katolickiej w Polsce, t. 2, cz. 1, red. M. Rechowicz, Towarzystwo Naukowe KUL, Lublin 1975.

Natoński B., Jezuici a Uniwersytet Krakowski w XVI w., w: Studia z historii jezuitów, Zaskale, Kraków 1983.

Natoński B., Ks. Jan Poplatek T.J. (1903-1955), „Nasza Przeszłość” 1957, t. 5.

Natoński B., Szkolnictwo jezuickie w Polsce w dobie kontrreformacji, w: Wiek XVII - Kontrreformacja - Barok, Zakład Narodowy im. Ossolińskich, Wrocław 1970.

Obirek S., Michał Jurkowski SJ. Autor „Historyi świeżych i niezwyczajnych”, Wydział Filozoficzny Towarzystwa Jezusowego, Kraków 1996.

Okoń J., Dramat i teatr szkolny. Sceny jezuickie XVII wieku, Zakład Narodowy im. Ossolińskich, Wrocław 1970.

Okoń J., Na scenach jezuickich w dawnej Polsce (rodzimość i europejskość), Uniwersytet Warszawski - Wydawnictwo DiG, Warszawa 2006.

Paszenda J., Działalność naukowa ks. Stanisława Bednarskiego SJ, „Nasza Przeszłość” 1993, t. 80.

Paszenda J., Budowle jezuickie w Polsce XVI-XVIII w., t. 1-5, Wyższa Szkoła Filozoficzno-Pedagogiczna "Ignatianum" - Wydawnictwo WAM, Kraków 1999-2013.

Piechnik L., Dzieje Akademii Wileńskiei, t. 1: Poczq̨tki Akademii Wileńskiei (1569-1600), Institutum Historicum Societatis Jesu, Rzym 1984.

Piechnik L., Dzieje Akademii Wileńskiej, t. 2: Rozkwit Akademii Wileńskiej w latach 1600-1655, Institutum Historicum Societatis Jesu, Rzym 1983.

Piechnik L., Dzieje Akademii Wileńskiej, t. 3: Próby odnowy Akademii Wileńskiej po klęskach Potopu i okres kryzysu 1655-1730, Institutum Historicum Societatis Jesu, Rzym 1987.

Piechnik L., Dzieje Akademii Wileńskiej, t. 4: Odrodzenie Akademii Wileńskiej 1730-1773, Institutum Historicum Societatis Jesu, Rzym 1990.

Piechnik L., Powstanie i rozwói jezuickiei „Ratio studiorum” (1548-1599), Wyższa Szkoła Filozoficzno-Pedagogiczna „Ignatianum" - Wydawnictwo WAM, Kraków 2003.

Piechnik L., Seminaria diecezjalne w Polsce prowadzone przez jezuitów od XVI do XVIII wieku, Wyższa Szkoła Filozoficzno-Pedagogiczna „Ignatianum” - Wydawnictwo WAM, Kraków 2001.

Poplatek J., Błogosławiony Andrzej Bobola Towarzystwa Jezusowego. Życie - męczeństwo kult, WAM, Kraków 1936.

Poplatek J., Komisja Edukacji Narodowej. Udział byłych jezuitów w pracach Komisji Edukacji Narodowei, uzup. L. Grzebień, WAM, Kraków 1973.

Poplatek J., Słownik jezuitów artystów, uzup. i wydał J. Paszenda, WAM, Kraków 1972.

Poplatek J., Studia z dziejów jezuickiego teatru szkolnego w Polsce, Zakład Narodowy im. Ossolińskich, Wrocław 1957.

Poplatek J., Zarys dziejów Seminarium Papieskiego w Wilnie 1585-1773, „Ateneum Wileńskie" 1930, t. 7, s. 170-228. 
Puchowski K., Jezuickie kolegia szlacheckie Rzeczypospolitej Obojga Narodów. Studium z dziejów edukacji elit, Wydawnictwo UG, Gdańsk 2007.

Rusnok A., Rękopiśmienne źródła do badań nad dziejami jezuitów w zbiorach Ksiqżnicy Cieszyńskiej oraz Archiwum Państwowego w Katowicach - Oddział w Cieszynie, w: Towarzystwo Jezusowe na Ślq̨sku Cieszyńskim, red. J. Budniak, K. Mozor, WAM, Kraków 2005.

Rzepiński S., Ks. Stanisław Załęski T.J., Sodalicja Mariańska Panów Ziemi Sądeckiej, Kraków 1908.

Tazbir J., Piotr Skarga, szermierz kontrreformacji, Wiedza Powszechna, Warszawa 1978, [wyd. 2. Warszawa 1983].

Wielewicki J., Dziennik spraw domu zakonnego OO. Jezuitów u św. Barbary w Krakowie, t. 5: 1630-1639, Wyższa Szkoła Filozoficzno-Pedagogiczna "Ignatianum" - Wydawnictwo WAM, Kraków 1999.

Załęski S., Jezuici w Polsce, t. 1: Walka z różnowierstwem, 1555-1608, Drukarnia Ludowa, Lwów 1900.

Załęski S., Jezuici w Polsce, t. 2: Praca nad spotęgowaniem ducha wiary i pobożności, 16081648, Drukarnia Ludowa, Lwów 1901.

Załęski S., Jezuici w Polsce, t. 3: Prace misyine nad ludem, 1648-1773, Drukarnia Ludowa, Lwów 1902.

Załęski S., Jezuici w Polsce, t. 4: Dzieje 153 kolegiów i domów jezuitów w Polsce, W.L. Anczyc, Kraków 1905.

Załęski S., Jezuici w Polsce, t. 5: Jezuici w Polsce porozbiorowei, 1773-1905, W.L. Anczyc, Kraków 1906.

\section{SUMMARY}

In the years 1564-1773, Jesuits ran colleges and schools in Eastern Europe, on the present territory of Poland, Lithuania, Latvia, Belarus and Ukraine. All the archives containing documents concerning these institutions and their history were, at the time of the dissolution of the Jesuit Order in 1773, destroyed or scattered. It was not until the $30 \mathrm{~s}$ of the $20^{\text {th }}$ century that a Jesuit, Stanisław Bednarski initiated collecting documentation in the form of photocopies from the central Archive in Rome and then from other Polish libraries. After his death and after the Second World War, Jan Poplatek, Bronisław Natoński and Ludwik Grzebień continued his work. Until the present time, almost the entire known documentation concerning the history of the Order in East-Central Europe has been collected in the form of photocopies, microfilms,
W latach 1564-1773 jezuici prowadzili we wschodniej części Europy kolegia i szkoły na terenie dzisiejszej Polski, Litwy, Lotwy, Białorusi i Ukrainy. Wszystkie archiwa zawierajqce dokumenty dotyczqce tych placówek i ich historii zostały w chwili kasaty zakonu w 1773 roku zniszczone lub rozproszone. Dopiero w latach 30. XX wieku jezuita Stanisław Bednarski rozpoczał w Krakowie gromadzenie dokumentacji w postaci fotokopii $z$ centralnego Archiwum w Rzymie, a następnie z innych bibliotek polskich. Po jego śmierci pracę tę kontynuowali po II wojnie światowej Jan Poplatek, Bronisław Natoński i Ludwik Grzebień. 


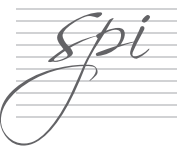

Do tej chwili zebrano w postaci fotokopii, mikrofilmów, kserokopii i dysków CD niemal cała znanq dokumentację dotyczq̨ca dziejów zakonu w Europie Środkowo-Wschodniej ze wszystkich archiwów i bibliotek europejskich. Dzięki tej dokumentacji powstało dotad kilkadziesiąt ksiqzżek naukowych i kilkaset artykułów dotyczących dziejów religijnych i kulturalnych tego regionu. Z ośrodka krakowskiego korzysta wielu historyków polskich i z krajów wschodniej Europy. W artykule ukazujemy historię ośrodka oraz podajemy opis i miejsce przechowywania zachowanych, a najważniejszych rękopisów dotyczqqych zakonu jezuitów, które zgromadzono w postaci różnej reprodukcji w Krakowie. Stanisław Bednarski nie przewidywał zapewne, że jego inicjatywa, przemyślane plany pozostawione na piśmie, w końcu dobre fundamenty położone pod wymarzony ośrodek naukowy, dadza tak znaczqce rezultaty. Jego też pamięci należy poświęcić ten skromny szkic historyczny. copies and CDs from all European archives and libraries. Owing to this documentation, several dozen scientific books and a few hundred articles concerning cultural and religious history of that region have been published. Many Polish and East European historians make use of the centre in Krakow. The article presents the history of the centre as well as the description and the location of the preserved, most significant manuscripts concerning the Jesuit Order, which have been collected in various forms of reproduction in Krakow. Apparently, little did Stanisław Bednarski expect that his initiative, carefully considered plans preserved in writing and, finally, the good foundation for his dream research centre, would bring such considerable results. Therefore, this humble historical sketch should be devoted to honour his memory.

\section{ADRES DO KORESPONDENCJI:}

Prof. dr hab. Ludwik Grzebień SJ

Katedra Historii Oświaty i Wychowania

Akademia Ignatianum w Krakowie

ul. Kopernika 26

31-501 Kraków 